\title{
Mimikri dan Hibriditas Novel Para Priyayi (Kajian Poskolonial)
}

\author{
Kadek Devi Kalfika Anggria Wardani
}

Universitas Pendidikan Nasional

Keywords:
mimicry;
hybridity;
postcolonial;

Kata kunci:

mimikri;

hibriditas;

poskolonial

\begin{abstract}
The practice of colonization in Indonesia which has been going on for three and a half centuries has caused a lot of changes, as a colonized nation. This was then clearly illustrated in the postcolonial literary works which were published at the time, including the novel Para Priyayi by Umar Kayam. Descriptions of real fiction and historical realities have given rise to mimicry and hybridity patterns. By reviewing the hermeneutic and descriptive methods, the following points were revealed. First, the symptoms of mimicry that appear in the novel Para Priyayi have three things, (1) mimicry in brew; (2) mimicry as an ideal ethic and category; (3) and local genius mimicry. Second, the symptoms of hybridity arise in the school environment, the leadership bureaucracy, and the establishment of schools and associations of youth organizations.
\end{abstract}

ABSTRAK

\begin{abstract}
Abstrak: Praktik koloniaslisme di tanah air yang berlangsung selama tiga setengah abad telah membawa banyak perubahan mendasar pada garis-garis kultural bangsa Indonesia, sebagai bangsa terjajah. Hal ini kemudian tergambar jelas dalam karya sastra poskolonial yang terbit kala itu, termasuk novel Para Priyayi karya Umar Kayam. Pendeskripsian realitas fiksi dan realitas historis tersebut telah memunculkan pola mimikri dan hibriditas. Berdasarkan pengkajian dengan metode hermeutika dan deskriptif berhasil diungkap beberapa hal berikut. Pertama, gejala mimikri yang muncul dalam novel Para Priyayi setidaknya mencakup tiga hal, yaitu (1) mimikri dalam berbahasa; (2) mimikri sebagai penyesuaian etika dan kategori ideal; (3) dan local genius mimikri. Kedua, gejala hibriditas muncul dalam lingkungan sekolah, birokrasi kepemimpinan, dan pendirian sekolah dan perhimpunan organisasi-organisasi pemuda.
\end{abstract}

Alamat Korespondensi:

e-mail: devikalfika@ymail.com

\section{Pendahuluan}

Kolonialisme atau penjajahan yang telah berlangsung di Indonesia lebih dari tiga setengah abad, telah mengakibatkan banyak perubahan mendasar pada garis-garis kultural bangsa Indonesia, sebagai bangsa terjajah. Dominasi budaya yang berlangsung secara intensif dalam waktu yang relatif lama telah menghasilkan tidak hanya hilangnya kekhasan lokal, namun lebih dari itu juga telah memupuk mental eropa sentris, budaya eropa menjadi sebuah budaya yang adiluhung serta dapat menjadi tolok ukur kebenaran dan justifikasi keunggulan adat istiadat. Hal tersebutlah yang kemudian merasuki mentalmental pribumi, dan seolah menjadi manusia yang beradab kalau sudah dapat berperilaku seperti orang eropa. Tidak hanya adat istiadat, bahkan segala konsep mental yang ada dalam benak pribumi selalu eropa sentris. Hanya sebagian kecil, orang-orang yang tetap merasa sebagai manusia-manusia inlander yang teguh mempertahankan kediriannya sebagai individu.

Pengaruh jejak-jejak kolonialisme tersebut secara lebih jelas kemudian tergambar dalam karyakarya poskolonial, misalya novel Para Priyayi, karya Umar Kayam. Novel Para Priyayi Novel adalah salah satu novel karya Umar Kayam yang sangat terkenal. Novel ini menceritakan mengenai seluk-beluk kehidupan priyayi. Priyayi merupakan sebuah kelas sosial tertinggi dalam masyarakat Jawa menurut Clifford Geertz. Geertz dalam bukunya "Abangan, Santri, Priyayi dalam Masyarakat Jawa" (1981) membagi masyarakat Jawa dalam tiga kelas sosial, yaitu priyayi, santri, dan abangan. Kelas yang berkedudukan paling tinggi adalah kelas priyayi. Para priyayi sebagian besar adalah keturunan raja-raja. Kelas yang 
berada di tengah adalah kelas santri yaitu masyarakat yang teguh menjalankan agama, sedangkan kelas paling bawah disebut kelas abangan atau yang sering disebut dengan istilah wong cilik yang terdiri dari golongan petani, buruh, maupun masyarakat desa dengan pendapatan dan pendidikan rendah.

Sebagai kelas sosial tertinggi dalam struktur sosial masyarakat Jawa, priyayi identik dengan perilaku yang adi luhung, perilaku yang baik dan terpuji sehingga pantas ditiru oleh kelas sosial lainnya. Akan tetapi Umar Kayam dalam novelnya ini mencoba untuk menampilkan sosok priyayi dari sudut pandang yang berbeda. Novel ini menceritakan tentang Soedarsono, seorang anak dari keluarga buruh tani yang oleh orang tua dan sanak saudaranya diharapkan dapat menjadi "sang pemula" untuk membangun dinasti keluarga priyayi kecil. Berkat dorongan Asisten Wedana Ndoro Seten ia bisa sekolah dan kemudian menjadi guru desa. Dari sinilah ia memasuki dunia elite birokrasi sebagai priyayi pangreh praja. Ketiga anaknya melawati zaman Belanda dan zaman Jepang tumbuh sebagai guru opsir peta dan istri asisten wedana.

Proses dan akibat praktik kolonialisme Belanda dan Jepang menjadi pengalaman estetis Umar Kayam dalam menulis novel Para Priyayi. Pendeskripsian realitas fiksi dan realitas historis tersebut telah memunculkan pola mimikri dan hibriditas. Pola tersebut menempatkan relasi bangsa penjajah dan bangsa terjajah dalam proses pembentukan identitas kultural dan identitas kebangsaan, baik dalam kategori ideal Barat maupun Timur. Bahkan, pertemuan dua peradaban tersebut memunculkan hibriditas dalam kehidupan elite birokrasi pemerintahan, dan pendidikan Hindia Belanda.

Kemunculan pola mimikri dan hibriditas tersebut, kemudian berimplikasi pada munculnya kekuatan local genius bangsa Idonesia untuk menghadapi penetrasi pengaruh Barat (Belanda). Oleh karena itu, pengungkapan realitas fiksi dan realitas historis dalam teks dan konteks poskolonial dalam novel Para Priyayi menjadi demikian penting dalam kehidupan berbangsa dan bernegara Indonesia. Kondisi tersebut yang melatarbelakangi penulis untuk menganalisis pola mimikri dan hibriditas yang terdapat dalam novel Para Priyayi. Hasil analisis ini penulis harap dapat dijadikan model terapan teori poskolonial dan model hibriditas kultural yang layak direvitalisasi dalam kehidupan modern bangsa Indonesia.

\section{Metode}

Metode yang digunakan dalam mengkaji gejala mimikri dan hibriditas dalam penelitian ini adalah metode hermeneutik dan deskriptif. Metode Hermeneutika merupakan sebuah studi pemahaman, khususnya pemahaman teks (Palmer, 2003:8). Metode ini mengedepankan ketepatan dalam memahami bahasa teks dalam konteks penafsiran dan konteks historis pemakaian bahasa tersebut. Prosedur yang ditempuh menggunakan metode ini meliputi tiga tahap (Hadi, 2004:91-92). Pertama, tahap pembacaan teks. Pada tahap ini dilakukan pembacaan terhadap teks novel Para Priyayi penuh kesungguhan, menggunakan sympathetic imagination (imajinasi yang penuh rasa simpati). Kedua, tahap penafsiran. Pada tahap ini , peneliti mulai menentukan tanda-tanda yang menunjukkan ciri-ciri atau tanda-tanda yang menunjukkan gejala mimikri dan hibriditas. Ketiga, tahap penafsiran. Pada tahap ini peneliti mulai mengaitkan tanda-tanda yang diidentifikasi pada tahap sebelumnya dengan fenomena yang diungkapkan dalam teks, kemudian juga mengaitkannya dengan citra fenomena masyarakat Indonesia saat ini .

Dari perspektif teoritik dan metadologik teori dan metode hermeneutika tidak dapat berdiri sendiri dalam menganalisis suatu teks sastra. Oleh karena itu, untuk membantu menjelaskan gejala mimikri dan hibriditas peneliti mengguakan metode deskriptif. Secara lebih mengkhusus peneliti menggunakan deskriptif analitik dan deskriptif komparatif. Deskriptif analitik dilakukan dengan cara mendeskripsikan fakta-fakta yang disusul dengan analisis. Deskriptif komparatif dilakukan dengan cara menguraikan dan membandingkan fakta-fakta kehidupan masyarakat Hindia Belanda sebagai suatu realitas fiksi dan realitas historis.

\section{Hasil dan Pembahasan}

\section{A. Mimikri dalam Novel Para Priyayi}

Analisis dan pembahasan mimikri dalam novel Para Priyayi ini difokuskan dalam tiga aspek, yaitu (1) mimikri dalam berbahasa; (2) mimikri sebagai penyesuaian etika dan kategori ideal; (3) dan local genius mimikri. 


\section{Mimikri dalam Berbahasa}

Sebagai salah satu novel yang banyak mengandung jejak kolonialisme, novel Para Priyayi banyak memunculkan bentuk-bentuk peniruan atau mimikri. Salah satu bentuk mimikri yang muncul dalam novel ini adalah mimikri cara berbicara bangsa Indonesia dengan menggunakan bahasa Belanda. Dalam novel ini digambarkan bahwa penguasaan bahasa Belanda memiliki peran yang penting untuk menunjukkan ciri kepriyayian seseorang dan sebagai akses untuk menempati posisi yang berkelas dalam sistem pemerintahan. Hal tersebut dapat ditunjukkan oleh dua kutipan berikut.

Noegroho sangat senang dan kuat dalam sejarah dan ilmu bumi, Hardojo kuat dalam bahasa Belanda dan mengarang meskipun kuat juga dalam berhitung, sedang Soemini, mungkin karena anak perempuan menurut saya sangat fasih bahasa Belandanya. Bahasa Soemini bukan sekedar een-twee-drie, tapi menurut kedua menir itu juga, bahasa Belanda yang betul baik. Sering kali kalau kedua menir itu mampir di rumah, Soemini pamer kepinteran Bahasa Belandanya itu dengan banyak berbahasa Belanda dengan guru-gurunya itu. Dia akan mengucapkan salam "goeie napen, meneer." Dan waktu guru-guru itu pulang "dah, meneer, tot sien". Dan diantara kalimat basa-basi Belanda itu banyak kalimat Belanda yang tidak saya ketahui. Wah, bangganya hati kami. Menurut istri saya, Soemini bahasa Belandanya sudah seperti nyonyah Belanda betul. (Kayam, 2012 : 66)

Anak-anak kami tentu saja tidak kami kirim ke sekolah desa. Sekolah desa diadakan untuk memenuhi keperluan yang sangat terbatas, yaitu untuk mendidik dan mengajar anak-anak desa bisa menjadi pemuka masyarakat desa, bisa menjadi buruh yang tahu membaca dan menulis, bisa menjadi juru tulis kelurahan. Dan kalau anak-anak desa itu beruntung, seperti saya misalnya, bisa mendapat kesempatan yang lebih baik. Anak-anak kami, kami masukkan ke sekolah HIS, sekolah dasar untuk anak-anak priyayi itu, karena sekolah ini diadakan untuk menyiapkan priyayi-priyayi gupermen. Anak-anak yang bersekolah di situ akan diajar bahasa Belanda, bahasa yang sangat penting buat mendapat kedudukan di kantor gupermen dan dapat meneruskan pelajaran ke sekolah menengah dan sekolah menengah atas priyayi, seperti MULO, AMS, atau sekolah-sekolah guru menengah, seperti sekolah Normaal, Kweek-sekul dan sebagainya itu. (Kayam, 2012 : 57)

Berdasarkan dua buah kutipan di atas, diketahui bahwa sebagai kelas sosial tertinggi dalam masyarakat Jawa, priyayi tidak dapat disamakan dengan kelas sosial lainnya. Misalnya saja dalam hal pendidikan, mereka bersekolah di sekolah khusus anak-anak priyayi yang memang disiapkan untuk menjadi guru maupun pejabat pemerintahan. Di sekolah tersebut mereka dididik dengan sistem pengajaran Belanda, sehingga mereka terbiasa dengan bahasa Belanda dan gaya hidup ala Barat. Bahasa Belanda bahkan menjadi bahasa yang sangat penting di sekolah-sekolah golongan priyayi tersebut. Di sekolah tersebut mereka juga dibiasakan untuk menyebut guru dengan panggilan "meneer" dan kepala sekolah dengan panggilan "school opziener", seperti yang tampak pada kutipan di bawah ini.

Di HIS guru-guru dipanggil sebagai "meneer". Tentu saja saya, tamatan sekolah desa lima tahun ditambah dengan kursus guru bantu dan sedikit pergaulan kesukan dengan priyayi kabupaten dan bahasa Belanda een-twee-drie dari Dik Ngaisah, tidak pernah juga dapat mengucapkan dengan pas kata "meneer" itu. Saya mengucapkan dengan "menir" saja. Apa boleh buat. (Kayam, $2012: 65$ - 66)

Begitu pentingnya penguasaan bahasa Belanda dipandang oleh kaum priyayi, hingga dalam memilih istri pun, hal tersebut juga menjadi salah satu bahan pertimbangan. Misalnya ketika Hardojo menimbang-nimbang Sumarti untuk menjadi istrinya, ia juga mempertimbangkan kemampuan bahasa Belanda Sumarti dan membandingkannya dengan adiknya, Soemini, yang disebutnya sebagai istri ideal salah satunya karena bahasa Belandanya yang bagus, seperti yang tampak dalam kutipan berikut.

Maka seorang anak perempuan Wonogiri yang tamat pendidikan HIS, sekolah dasar untuk anak-anak priyayi, adalah seorang gadis yang lebih dari cukup persiapannya untuk naik jenjang rumah tangga priyayi. Dengan penguasaan bahasa Belanda, sejarah, dan ilmu bumi ia 
akan tampil sebagai seorang yang cukup algemeen ontwikkeld, berpengetahuan umum. Bila dia akan kawin dengan seorang pangreh praja, dia akan sudah cukup mampu dan tidak kikuk untuk bergaul dengan istri atasan maupun nyonya kontrolir. Adik saya, Soemini, adalah salah seorang contohnya, meskipun pendidikan tambahannya di Van Deventer telah menambah kesiapannya lebih jauh lagi. Sebagai seorang istri asisten wedana dia adalah seorang istri yang ideal. Luwes, micara, bahasa Belandanya baik dan lancar, dan menguasai tata krama priyayi. ( Kayam, 2012 : 155)

Mimikri dalam hal berbahasa rupanya tidak hanya dilakukan oleh bangsa terjajah (Indonesia), tetapi juga dilakukan oleh bangsa penjajah, yakni bangsa Jepang, seperti yang tampak pada kutipan berikut.

"Ano, Tuan Sastrurodarrusono desu ka?"

"Ya..ya..Tuan Nippong"

“Tuan Darusono guru Karangdomporu desu ka?” (Kayam, 2012:140)

Mimikri tersebut muncul sebagai salah satu upaya bangsa penjajah untuk memperlancar komunikasi dengan bangsa terjajah.

Berdasarkan uraian di atas, dapat disimpulkan bahwa mimikri dalam hal berbahasa yang tergambar dalam novel Para Priyayi memiliki dua buah pola. Pertama, mimikri yang dilakukan oleh bangsa Indonesia dengan menggunakan bahasa Belanda sebagai penunjukan prestise seorang priyayi dan untuk mendekatkan diri dengan elite birokrasi. Kedua, mimikri yang dilakukan oleh bangsa penjajah dengan menggunakan bahasa Indonesia untuk memperlancar komunikasi dengan bangsa terjajah.

\section{Mimikri Sebagai Penyesuaian Etika dan Kategori Ideal}

Konstelasi penyesuaian etika dan kategori ideal terus-menerus terjadi dalam novel Para Priyayi. Konstelasi tersebut menghadapkan Barat dan Timur dalam ruang dan waktu yang sama untuk menunjukkan identitas kebangsaan sebagai bangsa penjajah dan bangsa terjajah. Bangsa penjajah direpresentasikan oleh bangsa Belanda dan Jepang sedangkan bangsa terjajah direpresentasikan oleh bangsa Indonesia. Pertemuan peradaban Barat dan Timur di Indonesia pada masa pemerintahan Hindia Belanda dan Jepang telah menimbulkan benturan peradaban. Etika dan kategori ideal siapa yang harus diwujudkan dalam pertemuan antarbangsa tidak dapat begitu saja diterima tanpa perlawanan. Apalagi, sebelum suatu peradaban diwujudkan telah muncul berbagai pandangan tentang peradaban tersebut. Oleh karena itu, tokoh-tokoh cerita dalam novel Para Priyayi menghadapi masalah peniruan etika dan kategori ideal dalam bermasyarakat.

Penyesuaian etika dan kategori ideal Barat dan Timur dideskripsikan oleh Umar Kayam melalui mimikri yang dilakukan oleh tokoh-tokoh yang ada dalam novel Para Priyayi. Peggambaran mimikri terhadap kategori ideal Barat, terutama mengenai gaya hidup, tergambar jelas pada tokoh Noegroho dan keluarganya. Berikut disajikan beberapa kutipan yang menggambarkkan hal tersebut.

Istri saya yang agak senang dengan makanan cara Belanda karena biasa dimanjakan ibunya yang pensiunan juru rawat Rumah Sakit Elizabeth, jadi agak terpukul dengan keadaan yang merosot itu. Langkah-langkahnya sebagai ibu rumah tangga jadi kikuk menghadapi keadaan yang serba kurang itu. Selama ini dia selalu senang memanjakan kami serumah. Di meja makan kami biefstuk daging has yang lengkap dengan segala kentang dan jus dan slada husar adalah hidangan yang tidak asing. Pagi hari selain sarapan nasi goreng dengan irisan keju dan telur dadar, anak-anak juga dibawakan sangu ke sekolah boterham, roti tawar dengan boter Belanda dan sele merk Betuwe dan entah apa lagi. Pakaian kami serumah juga seallu diawasi dan dijaga oleh istri saya dengan baik, artinya kulaitas baju-baju itu mestilah bagus, warna-warna dan potongannya tidak boleh kampungan. Dan setiap bulan, sekali dua kali sekeluarga kami juga suka makan di restoran Oen atau minum es krim Tip Top.

(Kayam, 2012: 196)

Dari penggalan kutipan di atas dapat diketahui bagaimana kehidupan keluarga Noegroho yang sangat meniru kategori ideal gaya hidup barat (Belanda), terutama dalam hal makanan. Semua makanan yang disebutkan di atas merupakan makanan khas barat yang tidak mungkin dinikmati oleh kalangan tertentu bagi masyarakat Indonesia. Seperti yang telah dijelaskan Susanti atau Suzie, istri Noegroho sudah terbiasa mengonsumsi makanan barat yang akhirnya juga ia lakukan pada rumah tangganya bersama Noegroho. 
Lebih lanjut juga diketahui bahwa mimikri atau peniruan terhadap konsep ideal barat yang dilakukan keluarga Noegroho tidak hanya dalam hal makanan saja, tetapi juga dalam hal pemberian nama panggilan Susanti dan anak-anak Noegroho yang mirip dengan nama nama-nama barat. Misalnya Susanti yang dipanggil Suzie, begitu pula dengan anak pertamanya Suhartono yang dipanggil Toni, Sumaryati yang dipanggil Marrie, dan Sutomo yang dipanggil Tommie. Nama-nama mereka sebenarnya merupakan nama Jawa, akan tetapi nama panggilan mereka merupakan nama barat yang sebenarnya tidak berhubungan dengan nama mereka meskipun jika diucapkan cukup mirip.

Sus, istri saya yang nama lengkapnya adalah Susanti dan sering juga dipanggil Suzie oleh ibunya, tidak habisnya mengeluh dengan keadaan itu.

(Kayam, 2012 : 196)

Saya masih belum bercerita tentang anak-anak saya. Pada tahun 1948 itu anak saya yang sulung, Suhartono, yang kami panggil Toni, sudah berumur enam belas tahun. Dia sudah duduk di kelas dua SMA bagian B di Kotabaru. Anak kami yang kedua adalah Sri Sumaryati, yang lebih akrab kami panggil Marrie, sebaya dengan Harimurti, anak Hardojo. Sedang yang bungsu laki-laki lagi, Sutomo, berumur sebelas tahun. Dia lebih banyak kami panggil sebagai Tommi.

(Umar Kayam, 2012 : 219)

Selain mimikri sebagai penyesuaian kategori ideal Barat dalam hal gaya hidup, mimikri juga terjadi dalam lingkungan akademik penyelenggaraan pendidikan yang berlatar belakang pendidikan Barat. Misalnya, dalam hal kebebasan untuk mengungkapkan pendapat. Dalam kultur masyarakat Jawa tradisional, anak perempuan tidak memiliki hak untuk mengemukakan pendapat secara terbuka dalam sebuah keluarga, terlebih menyangkut masalah perkawinan. Namun hal demikian tidak terjadi dalam keluarga Sastrodarsono. Sastrodarsono, yang telah mengenyam pendidikan barat, begitu pula dengan anakanaknya, membicarakan segala sesuatu yang menyangkut masalah keluarga dengan terbuka dengan memberikan kebebasan berpendapat sebebas-bebasnya terhadap putra-putrinya untuk mengungkapkan pendapat, termasuk ketika mendiskusikan masalah perkawinan, seperti yang tampak pada penggalan kutipan percakapan berikut.

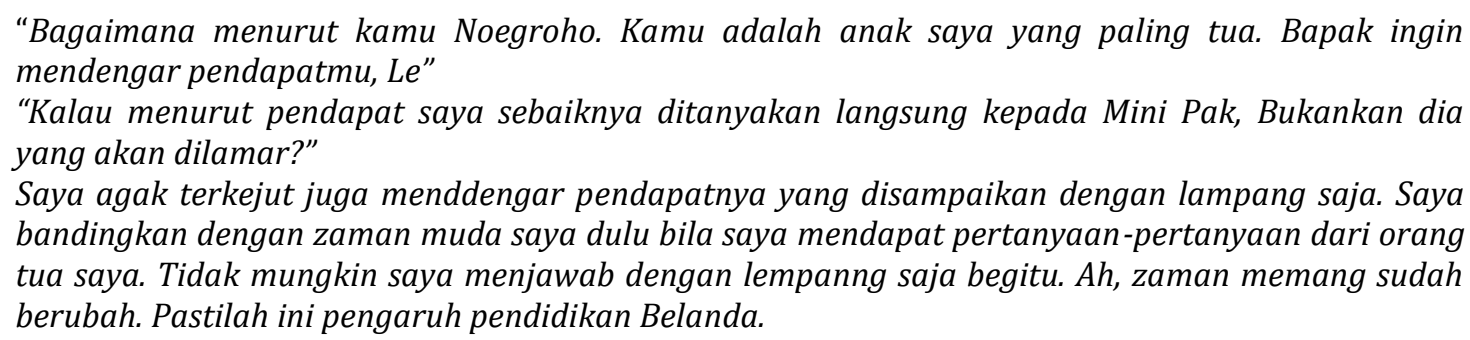
(Kayam, 2012:84)

Realitas fiksi lain yang dihadirkan untuk menggambarkan mimikri sebagai bentuk penyesuaian etika dan kategori ideal bangsa penjajah, ditunjukkan oleh tokoh Noegroho.

Memang keras, Yok, bahasa prajurit itu. dalam latihan di Bogor semangat setia kepada rajad dan negara itu juga ditekankan. Semangat bushido dari para samurai, para satria Jepang. Malah kalau seorang samurai tidak mampu melaksanakan tugasnya membela negara, dia akan hara-kiri, seppuku, membunuh dirinya sendiri.

"dan Mas Noeg sekarang setuju dengan semangat dan nilai itu?"

"Buat saya bukan lagi masalah setuju atau tidak, Yok. Ini masalah kewajiban"

(Kayam, 2012:205)

"Tetapi, kalau negara itu tidak benar, bukankah itu karena pemerintah atau rajanya yang tidak benar? Apakah kita harus tetap membelanya?"

"Kalau bukan prajurit memang tidak ada pilihan lain, kecuali memang harus membela negara. Itu kewajiban utamanya"

"Kalau bukan prajurit boleh tidak ikut membela, Mas Noeg?"

"Ya, kalau menurut saya, sebaiknya atau mungkin seharusnya ya harus juga ikut membela negara. Wong negaranya sendiri kok." 
(Kayam, 2012:205)

Di dalam realitas fiksi Para Priyayi, tokoh Noegroho sepulang mengikuti pelatihan PETA di Bogor tampak meniru semangat samurai, tentara Jepang, sehingga Noegroho dapat menyesuaikan diri dengan kehidupan barunya sebagai seorang tentara PETA (Pasukan Pembela Tanah Air).

Mimikri sebagai penyesuaian kategori ideal bangsa penjajah dalam lingkungan akademik penyelenggara pendidikan yang berlatar belakang pendidikan juga terlihat dari perilaku putri Noegroho, Marie. Marie yang telah menempuh pendidikan Barat sangat terpengaruh dengan pola pergaulan barat yang cenderung bebas, seperti yang tampak dalam kutipan di bawah ini

Marie, yang ditampung ayahnya di kantor bapaknya sebagai salah seorang sekretarisnya, tidak terlalu serius dengan pekerjaannya. Dia sering meninggalkan pekerjaan di tengah-tengah tugas untuk, misalnya berkencan makan siang dengan teman laki-laki untuk kemudian tidak kembali lagi ke kantorny. Atau seringkali begitu saja tidak masuk kantor dengan alasan kurang enak badan. Tetapi, ternyata pada siang harinya entah pergi kemana dengan teman laki-lakinya sampai sore hari.

(Kayam, 2012:146)

Mimikri yang dilakukan oleh Marie di atas, dalam realitas fiksi yang dihadirkan oleh Umar Kayam ternyata membawa dampak negatif terhadap Marie. Akibat pergaulan bebas, tokoh Marie menjadi hamil di luar nikah. Kehormatan Noegroho sebagai seorang priyayi menjadi tercoreng. Pada perkembangan berikutnya Noegroho dan istrinya Susanti mati-matian mengejar laki-laki yang telah menghamili Marie untuk bertanggung jawab.

Berdasarkan uraian di atas, diketahui bahwa mimikri dalam bentuk penyesuaian etika dan kategori ideal yang dilakukan oleh orang Indonesia terhadap kebudayaan bangsa penjajah dapat berakibat positif dan negatif.

\section{Local Genius Mimikri}

Mimikri sebagai peniruan atau penyesuaian etika dan kategori ideal dalam novel Para Priyayi terjadi pada kehidupan orang-orang Indonesia. Bangsa Indonesia sebagai representasi Timur memiliki cara tersendiri untuk mempertahankan identitas kulturalnya. Pemertahanan identitas kultural sebagai suatu kecerdasan lokal dalam realitas fiksi dan realitas historis dapat diidentifikasi melalui beberapa hal dalam novel ini.

Pertama, kecerdasan masyarakat Jawa tetap memertahankan identitas kulturalnya sebagai masyarakat petani. Hal tersebut ditunjukkan oleh kehidupan tokoh Sastrodarsono. Meskipun beliau merupakan seorang priyayi terpadang, yang pernah menduduki jabatan School Opziener dan digaji dengan tinggi oleh pemerintah Hindia Belanda, namun beliau tetap mempertahankan identitas kulturalnya sebagai seorang petani dengan tetap membuka lahan pertanian di belakang rumahnya.

Ndoro guru, meskipun priyayi mantra guru, juga bertani. Di belakang rumah Setenan itu ada Tegalan dengan berbagai macam tumbuh-tumbuhan, seperti singkong, juga uwi, semacam ubi yang berkulit hitam dan tumbuhnya menjalar di pohon, kemudian sudah tentu juga rumpun-rumpun bamboo di pojok-pojok tegalan. Di belakag tegalan adalah sawah yang beberapa bau luasnya.

(Kayam, 2012:16)

Le, kamu meski sudah jadi priyayi , jangan lupa akan asal-usulmu. Kacang masa akan lupa dengan lanjarann-nnya. Rumah tanggamu, meski rumah tangga priyayi, tidak boleh tergantung dari gajimu, Le. Jadi priyayi itu jadi orang terpandang kedudukannya, akrena kepinterannya. Kalau mau jadi kaya ya jadi saudagar, jadi bakul saja. Maka kalian supaya mandiri, tidak bergantung dari gaji priyayi saja, mesti masih sedikit-sedikit bertani.

(Kayam, 2012:53)

Sastrodarsono yang sedari kecil telah banyak menerima pengaruh barat, diceritakan sebenarnya tidak memiliki ketertarikan sama sekali dengan dunia pertanian, oleh karena itu ia kemudian menjadi pegawai yang digaji gupernen. Tetapi Sastrodarsono selalu merasa untuk tetap setia pada asalnya, yaitu keluarga petani Jawa.

Kedua, kecerdasan masyarakat Jawa memfilter dampak negatif yang dapat ditimbulkan pendidikan barat dengan kultur budaya masyarakat Jawa melalui petuah Jawa. Misalnya, ketika Romo 
Seten menasihati Sastrodarsono agar tetap memegang prinsip roso rikuh dalam masyarakat Jawa. Pendidikan barat yang dienyam oleh Sastrodarsono hendaknya jangan sampai membuat ia menjadi serakah dan takabur, prinsip roso rikuh itu harus tetap dipegang teguh.

Priyayi yang baik itu Le, harus sadar akan roso rikuh. Alangkah akan mengerikannya bila seorang priyayi itu tidak memiliki roso rikuh, kata beliau selanjutnya. Dia akan tampil sebagai seorang priyayi yang tidak punya kepekaan terhadap perasaan dan mungkin juga terhadap pernderitaan orang lain. Priyayi yang tidak tahu rikuh itu Le, di bawah lubuk hatinya adalah orang yang sesungguhnya serakah dan mau menang sendiri, tergas beliau. Akan tetap rikuh itu tidak berarti tidak berani berbuat apa-apa, Iho le, tegas beliau lagi. Priyayi yang punya roso rikuh justru harus tahu kapan harus bertindak dan tidak merasa rikuh lagi. Beliau menutup petuahnya.

(Kayam, 2012:110)

Contoh lain ditunjukkan ketika Soedarsono menyadari pelajaran budi pekerti yang ia tanamkan berhasil membentengi anaknya untuk berperilaku tidak sopan (yang dipandangnya sebagai salah satu pengaruh pendidikan barat). Berikut disajikan kutipan yang menguatkan hal tersebut.

Untunglah anak-naak saya itu, meskipun mulai seenaknya mengemukakan pikiran mereka kepada orang tua, masih terpelihara tata kramanya. Mereka tidak kurang ajar kepada kami, masih sopan, dan bahasa Jawanya masih lengkap. Itu membesarkan hati saya. Setidaknya pendidikan kami di rumah tidak sia-sia. Pelajaran budi pekerti yang saya masukkan lewat ceritera-ceritera wayang rupanya ada pengaruhnya juga.

(Kayam, 2012:89)

Ketiga, peranan para wanita dalam menghadapi kultur Barat diperlihatkan dengan cara meniru sekaligus menampakkan identitas kulturalnya. Hal tersebut ditunjukkan oleh tokoh wanita yang menjadi istri para priyayi. Istri para priyayi yang digambarkan dalam novel Para Priyayi akibat pengaruh kultur barat, umumnya mengenyam pendidikan yang cukup tinggi. Meskipun mereka memiliki bekal pendidikan yang tinggi, hal ini tidak serta merta membuat mereka menempati posisi yang tinggi dalam birokrasi pemerintahan. Para wanita tersebut tetap menunjukkan identitas kultural mereka sebagai wanita Jawa, dengan tetap menjadi ibu rumah tangga.

Tentulah saya percaya kepada penilaian istri saya itu. bukankah ibunya anak-anak dulu pernah ikut ndoro nyonyah administrator pabrik gula Mabalong? Tetapi eh, tahu-tahu Soemini sudah kelas lima, dua tahun lagi da sudah akan tamat HIS. Latas mau kami apakan dia? Sepintar-pintar Soemini dia itu anak perempuan. Emang saya dan istri saya adalah pendukung Raden Ajeng kartini dan kami buktikan itu dengan memberi kesempatan Soemini bersekolah di HIS, kami tidak pingit atau kungkung di rumah, kami belikan sepeda, kami bolehkan belajar menari di pendopo kabupaten dan kami biarka dia pergi kemana saja, asal minta izin kami dulu dan tidak pergi sesudah amtahari tenggelam. Bukankah kami cukup maju? Akan tetapi anak perempuan adalah anak perempuan. Pada akhirnya, dia akan harus kawin dan membangun keluarga, membesarkan anak, membuat suaminya dan keluarganya bahagia.

(Kayam, 2012: 73)

Keempat, di dalam novel Para Priyayi terdapat local genius sistem kekeluargaan. Hal ini terlihat dari cara para priyayi menyelesaikan masalah keuangan dan pendidikan. Masalah keuangan keluarga diatasi dengan cara menerima bantuan dari keluarga yang sudah berhasil dalam kariernya. Sistem kekeluargaan ini tetap mengukuhkan keluarga besar pengarang sebagai keluarga yang berpendidikan Barat. Kekuatan local genius yang mengandalkan sistem kekeluargaan ini juga dipraktikkan dalam hal pendidikan. Dalam novel ini digambarkan, masyarakat petani Jawa, ramai-ramai menyekolahkan anak mereka supaya menjadi priyayi, agar mampu memberikan kesempatan keluarga lainnya yang kurang beruntung untuk menikmati jenjang pendidikan. Sistem kekeluargaan yang begitu kuat inilah yang kemudian membantu keluarga besar priyayi berhasil keluar dari berbagai kesulitan hidup di masa pemerintahan kolonial Hindia Belanda. berikut disajikan beberapa kutipan yang menguatkan hal tersebut.

Rumah tangga ndoro guru adalah rumah tangga khas priyayi Jawa, dimana sang priyayi adalah juga soko guru keluarga besar yang berkewajiban menampung sebanyak mungkin anggota keluarga jaringan itu ke dalam rumah tangganya. Rezeki dan pangkat itu jangan dimakan dan dikang-kangi sendiri, begitulah saya dengar ndoro guru berkali-kali menasehati anak-anaknya dan siapa saja. Tidak pantas, saru, bila ada seseorang anggota keluarga besar priyayi sampai kleleran, 
terbengkalai, jadi gelandangan tidak ada yang mengurus, tidak menikmati pendidikan, begitu nasihatnya yang lain. Priyayi yang tidak urus begitu adalah priyayi yang jelek bahkan bukan priyayi kean ndoro guru lebih jauh

(Kayam, 2012:17)

\section{B. Hibriditas dalam Novel Para Priyayi}

Pertemuan kebudayaan Barat dan Timur dalam kolonialisasi di Indonesia telah memunculkan kebudayaan baru. Kebudayaan baru sebagai sebuah hibriditas dalam wacana poskolonial menjadi sesuatu yang penting sebagai penanda jejak-jejak kolonialisme. Bentuk-bentuk hibriditas dalam novel Para Priyayi dapat diidentifikasi melalui hal-hal berikut.

Pertama, hibriditas dalam novel Para Priyayi terjadi dalam lingkungan sekolah. Secara struktural, sekolah dalam novel ini berfungsi sebagai lembaga pembentuk hibriditas kultural. Hal ini terjadi dalam kehidupan Sastrodarsono dan Lantip yang mengalami perubahan identitas kultural dari "anak petani" menjadi "priyayi". Gelar "priyayi" dalam kebudayaan Jawa yang semula hanya digunakan untuk menyebut orang berdarah biru yang memiliki keturunan dari keluarga kerajaan, dalam novel ini diceritakan telah mengalami pergeseran makna. Dalam novel ini digambarkan bahwa gelar priyayi juga bisa diperoleh seseorang yang memiliki pendidikan tinggi, terpelajar, dan memiliki jabatan dalam sistem birokrasi Belanda. Dalam hal ini sekolah kemudian dipandang sebagai sebuah lembaga yang mampu "menyulap" seorang anak petani" menjadi "priyayi". Hal inilah yang terjadi pada Sastrodarsono dan Lantip. Soedarsono dan Latip oleh orangtua dan sanak saudaranya diharapkan dapat menjadi "sang pemula" untuk membangun dinasti keluarga priyayi kecil. Berkat dorongan asisten Wedana Ndoro Seten, mereka kemudian bersekolah dan menjadi guru desa. Dari sinilah ia memasuki dunia elite birokrasi sebagai priyayi pangreh praja. Berikut disjaikan sebuah kutipan yang menunjukkan hal tersebut.

Hari itu saya Soedarsono, anak tunggal Mas Atmokasan, petani Kedungsimo, pulang dari Madiun dengan berhasil mengantongi beslit guru bantu di Ploso. Guru Bantu, itu berarti sayalah orang pertama dalam keluarga besar kami yang berhasil menjadi seorang priyayi, meskipun priyayi yang paling rendah tingkatannya. Itu tidak mengapa. Yang penting kaki saya sudah melangkah masuk jenjang priyayi. Beberapa tahun lagi, kalau saya rajin dan setia kepada Gupermen, saya akan menjadi guru penuh sekolah desa. Itu akan lebih memantapkan lagi kedudukan saya sebagai priyayi, sebagai abdi gupermen. Dan kalau saya sudah menjadi mantri guru, wah itu sudah boleh dikatakan saya menjadi seorang priyayi yang terpandang.

(Kayam, 2012:32)

Demikin juga dengan pamn-paman dan pakde saya semuanya petani desa. Semua dari keluarga besar kami itu, seperti juga kebanyakan keluarga petani desa, menginginkan pada suatu waktu salah seorang anggota keluarganya bisa maju menjadi priyayi dan tidak berhenti dan puas menjadi petani desa saja.

(Kayam, 2012:33)

Berdasarkan penjelasan di atas, pola hibriditas kultural yang tampak dalam novel Para Priyayi mempertimbangkan hibriditas struktural sebagai representasi bangsa penjajah dan bangsa terjajah atau representasi pendidikan Barat dan etika Timur. Hal tersebut ditunjukkan oleh adanya kepercayaan masyarakat untuk mengubah status mereka dari seorang petani menjadi priyayi melalui lembaga pendidikan.

Hibriditas yang digambarkan oleh Umar Kayam tersebut tampaknya didasarkan pada kenyataan sebagaimana diungkapkan oleh Soekiman (2011:14) bahwa, "Masyarakat kolonial di Hindia Belanda memiliki struktur yang bersifat (semi) feodal. Mereka mengalami modernisasi karena masyarakatnya tumbuh sejalan dengan perkembangan sistem produksi dan teknologi." Oleh karena itu, perkembangan tingkat pendidikan menjadi prasyarat mutlak dalam proses hibridisasi yang dimulai oleh pembangunan perangkat birokrasi sebagai representasi hibridisasi struktural yang membentuk hibridisasi kultural. Faktor pendidikan ini akan menempatkan bangsa terjajah berkedudukan setara dengan bangsa penjajah dalam menerima kepemimpinan modern yang belum dikenal secara meluas dalam kebudayaannya.

Kedua, bentuk hibriditas juga hadir dalam hal birokrasi kepemimpinan. Model dan wujud kepemimpinan dalam proses hibriditas dalam realitas fiksi diungkapkan oleh Umar Kayam dalam novel Para Priyayi. Masyarakat Jawa yang telah mengalami kolonisasi, mendapatkan pengaruh yang cukup banyak dalam hal birokrasi kepemimpinan. Hal tersebut dapat diketahui dari adanya posisi 
kepemimpinan yang merupakan adaptasi dari birokrasi kemimpinan Belanda, misalnya seperti school opziener, opziener, polisi, dan gupermen, seperti yang ditunjukkan oleh beberapa kutipan berikut.

Rupanya pemilik sekolah, School Opziener, memerhatikan dengan cukup seksama cara saya mengajar. Pada waktu hari rutin penilikan, saya dipanggil beliau di ruang mantri.

(Kayam, 2012:59)

Dik Ngaisah ternyata gugup dan takut sesudah saya ceritakan tentang percakapan saya dengan opziener dan Mas Martoatmojo, apalagi sesudah melihat-lihat surat kabar Medan Priyayi (Kayam, 2012:63)

Mantra penjual candu itu orang yang dipercaya negoro gupermen lho, le. Kita harus tampil gagah, meski cuma petani saja.

(Kayam, 2012:43)

Rupanya Mas Martoarmojo sudah lama tahu kalau semua gerak-geriknya diamati bukan hanya oleh Opziener tetapi juga oleh Polisi.

(Kayam, 2012:62)

Posisi birokrasi kepemimpinan yang merupakan adaptasi dari birokrasi kemimpinan Belanda tersebut dibentuk berdampingan dengan sistem birokrasi kepemimpinan masyarakat Jawa yang telah ada sebelumnya, seperti wedana, dan raja serta memiliki fungsinya masing-masing.

Ternyata apa yang dibayangkan oleh Bapak Wedana, utusan istana Mangkunegara benar. Saya tidak hanya diterima dan diberi penjelasan panjang lebar tentang jangkauan tugas tersebut oleh pejabat tinggi Mangkunegara, tetapi pada hari terakhir juga diterima oleh Kanjeng Gusti sendiri. (Kayam, 2012:171)

Tidak lama kemudian kanjeng gusti keluar dari dalam. Beliau berpakaian Jawa, berjas beskap landing berwarna kuning gading, memakai blangkon dan kain. Kami berdua segera berdiri dan memberi hormat dengan sembah.

(Kayam, 2012:172)

Ketiga, hibriditas dalam novel Para Priyayi terjadi dalam pendirian sekolah dan perhimpunan organisasi-organisasi pemuda. Pengarang menghadirkan berbagai organisasi dalam realitas fiksi sebagaimana terjadi dalam realitas historis Indonesia. Organisasi yang hadir dalam realitas fiksi yang digambarkan oleh Umar Kayam antara lain; Partai Nasional Indonesia (PNI), Medan Priyayi, Sarekat Dagang Islam, PETA, dan Heiho, seperti yang tampak pada beberapa kutipan di bawah ini.

\section{"Apa hubungan Kang Mas dengan Sarekat Dagang di Lawean itu?"}

(Kayam, 2012:62)

"Dimas Sastro tertarik dengan Medan Priyayi? Bawalah kalau memang tertarik untuk membacanya. Tetapi mingguan ini tidak boleh terbit lagi. Pemimpinnya sudah dihukum dan dibuang" (Kayam, 2012:62)

"Hati -hati, lho, Pak. Jangan sampai usaha Bapak yang baik ini dikaitkan dengan Pakde Marto. Pakde Martoarmojo, meski sudah pertikelir, menurut Mas Harjono terus diawasi Gupermen. Dia malah diduga sekarang ada hubungan dengan orang PNI."

(Kayam, 2012:116)

Pendirian berbagai organisasi sebagai bentuk hibriditas struktural tersebut dalam perjalanan hidup tokoh Sastrodarsono memunculkan berbagai hibriditas kultural. Realitas fiksi tokoh Sastrodarsono berpusat pada kehidupannya sebagai seorang guru di Karangdompol, Kabupaten Wanagalih. Di sekolah ini, Sastrodarsono menerapkan keterbukaan budaya akademis, sehingga dia memaparkan program-program 
peningkatan kualitas dan kuantitas pendidikan di sekolah tersebut. Bahkan, dia menjelaskan kondisi keuangan sekolah dan perhitungan gaji kepada para guru. Keterbukaan Sudarmo dalam memimpin pengelolaan sekolah tampaknya masih belum memuaskan masyarakat. Masyarakat meminta Sastrodarsono untuk membangun sebuah sekolah di desa Wanalas. Keinginan itu dipenuhinya, ia membangun sebuah sekolah khusus untuk pribumi di desa Wanalas, dengan biaya oprasional sendiri. Berikut disajikan beberapa kutipan yang menunjukkan hal tersebut.

Mas Martoatmojo kemudian minta tolong kepada saya apakah saya tidak dapat menolong menanyakan kemungkinan membuka sekolah desa yang tiga tahun saja dulu di desa Wanalas.

(Kayam, 201:112)

Dalam perundingan itu akhirnya saya memutuskan bahwa akan dicoba dengan satu kelas kecil untuk pelajaran membaca dan menulis. Kelas tersebut akan dibuka untuk anak-naak yang berumur tujuh tahun dan yang sudah lebih tua dari itu tetapi belum pernah mendapat kesempatan sekolah. Kami juga mempertimbangkan kesempatan untuk menyediakan waktu bagi orang-orang tua yang berminat untuk belajar membaca dan menulis.

(Kayam, 2012:115)

Akan tetapi, niat baik Sastrodarsono ini kemudian dipandang sebagai sebuah bibit pemberontakan oleh pihak Belanda, sekolah ini kemudian tidak bertahan lama dan dibubarkan. Sastrodarsono merasa sangat malu dan sedih akan ketidakberdayaannya menghadapi Belanda tersebut, seperti yang ditunjukkan oleh kutipan berikut.

Akan tetapi, sesudah sekolah itu berjalan dengan lumayan lancar, rupanya Gusti Allah tidak mengizinkan saya untuk meneruskan usaha saya. Belum lagi setahun usaha saya itu berjalan, saya harus menghentikan usaha kebanggan kami dan menutup untuk selamanya. Bukan main sedih, remuk hati saya. Bukan main malu saya terhadap orang-orang Wanalas itu.

(Kayam, 2012:118).

Berdasarkan penjelasan di atas, hibriditas dalam realitas fiksi dan realitas historis novel Para Priyayi dimulai dari sistem pendidikan seperti HIS, MULO, AMS, dan NIAS. Lembaga pendidikan ini menerima pribumi sebagai pelajar dan mahasiswanya, terutama pribumi yang berlatar belakang priyayi dan anak-anak berprestasi luar biasa sebagaimana terjadi pada Satrodarsono dan Lantip. Satrodarsono dan Lantip sebagai representasi orang Timur terjebak dalam hibriditas struktural dan kultural sebelum akhirnya menemukan identitas kultural dan kebangsaannya.

Berdasarkan penjelasan di atas, hibriditas yang muncul dalam realitas fiksi dan realitas historis novel Hindia Belanda berkesesuaian dengan biografi teori hibriditas Bhabha yang dituis oleh Huddart (2006:84), bahwa hibriditas merupakan permasalahan representasi kolonial dan individuasi yang membalikkan efek dari penyangkalan kolonial, sehingga pengetahuan yang lain ditolak masuk dalam proses hibridisasi yang sedang memperkuat basis otoritasnya. Artinya, terdapat perlawanan dan negosiasi terus-menerus untuk memperkuat basis otoritas kekuasaan sebelum tercipta sesuatu yang baru dan tidak dikenal dalam pola kepemimpinan, baik bagi bangsa penjajah maupun bangsa terjajah. Dengan demikian, relasi bangsa terjajah dengan bangsa penjajah (Belanda dan Jepang) berlangsung dalam tegangan otorisasi kekuasaan. Hal ini disebabkan hibridisasi struktural dikuasai oleh bangsa penjajah tetapi dalam hibridisasi kultural dikuasai oleh bangsa terjajah dalam proses penjajahan Belanda di Indonesia.

\section{Simpulan}

Melalui kajian ini dapat disimpulkan beberapa hal berikut.

1) Bentuk mimikri yang terdapat dalam novel Para Priyayi dapat diidentifikasi dalam tiga aspek, yaitu (i) mimikri dalam berbahasa; (ii) mimikri sebagai penyesuaian etika dan kategori ideal; (iii) dan local genius mimikri. Mimikri dalam hal berbahasa yang tergambar dalam novel Para Priyayi memiliki dua buah pola. Pertama, mimikri yang dilakukan oleh bangsa Indonesia dengan menggunakan bahasa Belanda sebagai penunjukan prestise seorang priyayi dan untuk mendekatkan diri dengan elite birokrasi. Kedua, mimikri yang dilakukan oleh bangsa penjajah dengan menggunakan bahasa Indonesia untuk memperlancar komunikasi dengan bangsa terjajah. 
Mimikri dalam bentuk penyesuaian etika dan kategori ideal yang dilakukan oleh orang Indonesia terhadap kebudayaan bangsa penjajah ternayata dapat berakibat positif dan negatif. Akibat positif dari mimikri terhadap penyesuaian etika dan kategori ideal yang dilakukan oleh orang Indonesia terhadap kebudayaan bangsa penjajah dapat dilihat dari peniruan kebiasaan hidup dan sikap penjajah, seperti budaya tepat waktu, disiplin, dan kesetiaan bangsa dan negara. Dampak negatif dari penyesuaian etika dan kategori ideal yang dilakukan oleh orang Indonesia terhadap kebudayaan bangsa penjajah dapat dilihat dari pergaulan bebas yang dilakukan oleh tokoh yang mengalami pendidikan barat.

Terdapat beberapa local genius mimikri yang dapat teridentifikasi dalam novel Para Priyayi. Pertama, kecerdasan masyarakat Jawa tetap memertahankan identitas kulturalnya sebagai masyarakat petani. Kedua, kecerdasan masyarakat Jawa memfilter dampak negatif yang dapat ditimbulkan pendidikan barat dengan kultur budaya masyarakat Jawa melalui petuah Jawa. Ketiga, peranan para wanita dalam menghadapi kultur Barat diperlihatkan dengan cara meniru sekaligus menampakkan identitas kulturalnya. Keempat, di dalam novel Para Priyayi terdapat local genius sistem kekeluargaan.

2) Hibriditas dalam novel Para Priyayi dapat diidentifikasi dalam beberapa lingkungan. Pertama, hibriditas dalam novel Para Priyayi terjadi dalam lingkungan sekolah, yang secara struktural berfungsi sebagai lembaga pembentuk hibriditas kultural. Kedua, bentuk hibriditas juga hadir dalam hal birokrasi kepemimpinan. Masyarakat Jawa yang telah mengalami kolonisasi, mendapatkan pengaruh yang cukup banyak dalam hal birokrasi kepemimpinan. Hal tersebut dapat diketahui dari adanya posisi kepemimpinan yang merupakan adaptasi dari birokrasi kemimpinan Belanda, misalnya seperti school opziener, opziener, polisi, dan gupermen. Ketiga, hibriditas dalam novel Para Priyayi terjadi dalam pendirian sekolah dan perhimpunan organisasiorganisasi pemuda.

\section{Referensi}

Ashcroft, Bill, Gareth Griffiths, dan Helen Tiffin. 2003. Menelanjangi Kuasa Bahasa: Teori dan Praktik Sastra Poskolonial (Dialihbahasakan oleh Fati Soewandi dan Agus Mokamat dari The Empire Writes Back: Theory and Practice in Post-colonial Literatures). Yogyakarta: Qalam.

2007. Post-colonial Studies: The Key Concepts Second Edition. New York-London: Routledge Taylor \& Francis e-Library.

Atmodjo, M.M. Sukarto K. 1986. “Pengertian Local Genius dan Relevansinya dalam Modernisasi.” Dalam Ayatrohaedi (ed.). Kepribadian Budaya Bangsa (Local Genius). Jakarta: Pustaka Jaya.

Barker, Chris. 2011. Cultural Studies: Teori dan Praktik (Diterjemahkan oleh Nurhadi dari Cultural Studies, Theory and Practice). Yogyakarta: Kreasi Kencana.

Bhabha, Homi. 1984. "Of Mimicry and Man: The Ambivalence of Colonial DiscourseAuthor," dalam Discipleship: A Special Issue on Psychoanalysis, Oktober 1984, Volume 28, Halaman 125-133, Dipublikasikan oleh The MIT Press, Diunduh dari http://www.jstor.org tanggal 31 Januari 2011. 1994. The Location of Culture. London dan New York: Routledge Taylor \& Francis e-Library.

Fanon, Frantz. 2008. Black Skin, White Masks (translated from the French by Richard Philcox). New York: Grove Press.

Hadi W.M., Abdul.2004. Hermeutika, Estetika, dan Religiusitas.Yogyakarta:Matahari

Haryono, Timbul. 1986. "Pembahasan Local Genius dalam Pranata Sosial.” Dalam Ayatrohaedi (ed.). Kepribadian Budaya Bangsa (Local Genius). Jakarta: Pustaka Jaya.

Huddart, D avid. 2006. Homi K. Bhabha: Routledge Critical Thinkers. London-New York: Routledge Taylor \& Francis e-Library.

Palmer, Richard E.2003.Hermeutika, Teori Baru Mengenai Interpretasi, terj. Musnur Hery . Yogyakarta:Pustaka Pelajar

Poespowardojo, Soerjanto. 1986. "Pengertian Local Genius dan Relevansinya dalam Modernisasi." Dalam Ayatrohaedi (ed.). Kepribadian Budaya Bangsa (Local Genius). Jakarta: Pustaka Jaya.

Ratna, Nyoman Kutha. 2007. Sastra dan Cultural Studies: Representasi Fiksi dan Fakta. Yogyakarta: Pustaka Pelajar

2008. Postkolonialisme Indonesia: Relevansi Sastra. Yogyakarta: Pustaka Pelajar

Said, Edward W. 1993. Culture and Imperialism. London: Alfred A. Koff, Inc.

-----. 1994. Orientalisme (Diterjemahkan oleh Asep Hikmat dari Orientalism). Bandung: Pustaka. 
-----, 2005. Bukan Eropa: Frued dan Identitas Politik Timur Tengah (Diterjemahkan oleh L.P. Hok dari Frued and the Non-European dengan artikel perkenalan Christopher Bollas dan Tanggapan Jacqueline Rose). Tangerang: Marjin Kiri.

Soekiman, Djoko. 2011. Kebudayaan Indis: Dari Zaman Kompeni sampai Revolusi. Depok: Komunitas Bambu. 